Resurrection and the Restoration of Israel 



$$
\text { J O N D. LEVENSON }
$$

\section{Resurrection and the Restoration of Israel}

THE ULTIMATE VICTORY OF THE GOD OF LIFE

Yale University Press

New Haven \&

London 
Quotations from the Hebrew Bible are (unless otherwise noted) reprinted from Tanakh: The Holy Scriptures, (C) I985, published by The Jewish Publication Society, with the permission of the publisher.

The Scripture quotations from the New Testament contained herein are from the New Revised Standard Version Bible, copyright $\odot$ I 989 by the Division of Christian Education of the National Council of Churches in the U.S.A., and are used by permission. All rights reserved.

Parts of this book were originally published as the following articles and appear here in substantially reworked form:

"The Fact of Death and the Promise of Life in Israelite Religion," in The Papers of the Henry Luce III Fellows in Theology, vol. VI, ed. Christopher I. Wilkins (2003), pp. I39-54. Reprinted with permission of the Henry R. Luce III Fellows Program and the Association of Theological Schools.

"Resurrection in the Torah: A Second Look," CTI Reflections 6 (2002): 2-29. Reprinted with permission of the Center of Theological Inquiry.

"The Resurrection of the Dead and the Construction of Personal Identity in Ancient Israel," in Congress Volume: Basel 2001, ed. A. Lemaire (2002), pp. 305-22. Reprinted with permission of Koninklijke Brill N.V.

Copyright $(\underset{2}{2} 2006$ by Yale University.

All rights reserved.

This book may not be reproduced, in whole or in part, including illustrations, in any form (beyond that copying permitted by Sections I07 and I08 of the U.S. Copyright Law and except by reviewers for the public press), without written permission from the publishers.

Set in Sabon Roman types by Keystone Typesetting, Inc., Orwigsburg, Pennsylvania. Printed in the United States of America by Sheridan Books, Chelsea, Michigan.

\section{Library of Congress Cataloging-in-Publication Data}

Levenson, Jon Douglas.

Resurrection and the restoration of Israel: the ultimate victory of the God of life / Jon D. Levenson.

p. cm.

Includes bibliographical references and index.

ISBN-I 3: 978-0-300-I I 735-6 (hardcover)

ISBN-IO: O-300-I I 735-3 (hardcover)

I. Resurrection (Jewish theology) 2. Jews-Restoration. 3. Bible. O.T. - Criticism, interpretation, etc. I. Title.

BM645.R47L48 2006

$296.3^{\prime} 3-\mathrm{dc} 22$

2006003 II 3

A catalogue record for this book is available from the British Library.

The paper in this book meets the guidelines for permanence and durability of the Committee on Production Guidelines for Book Longevity of the Council on Library Resources.

I0 988765432 I 
To the memory of my mother, Ethyl S. Levenson 
"The LoRD guards the loyal ['émûnim]." This is the people Israel, who recite, "Blessed be He who revives the dead," and answer "Amen" ['ämēn] with complete trust ['émûnâ]], for they trust [ma'ămînim] with all their strength in the Holy One (blessed be He!) that He will revive the dead, even though the resurrection of the dead has not yet come about. They recite, "who redeems Israel," even though they have not yet been redeemed, and "Blessed is He who rebuilds Jerusalem," even though it has not yet been rebuilt. Said the Holy One (blessed be He!): "They were redeemed only for a short time and then they were once again subjugated, yet they trust [ma'ăminnim] in Me that I will redeem them in the future." Hence, "The Lord guards the loyal ['ěmûnim]." -Midrash Tehillim to Psalm 3 1:24 